\title{
顔特徵点追跡による単眼視線推定
}

\section{Gaze Estimation with a Single Camera Using Facial Feature Tracking}

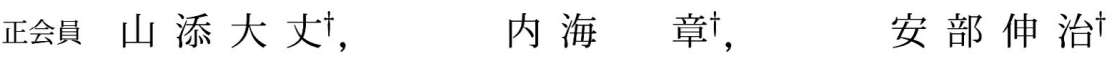

Hirotake Yamazoe ${ }^{\dagger}$, Akira Utsumi ${ }^{\dagger}$ and Shinji $\mathrm{Abe}^{\dagger}$

\begin{abstract}
We propose a real-time gaze estimation method based on facial-feature tracking using a single video camera. In ourq method, gaze directions are determined as $3 \mathrm{D}$ vectors connecting both the eyeball and iris centers. Since the center of eyeball cannot be directly observed from images, the geometrical relationship between the eyeball centers and the facial features and the radius of the eyeball (face model) are calculated in advance (calibration process). The 2D positions of the eyeball centers can be estimated by using the face model and facial feature positions. Gaze direction can then be determined by tracking the facial features. In the calibration process, we employ an image sequence (more than three frames) where a subject moves his/her head while keeping his/her gaze on the camera location. In such a situation, since the camera, iris centers and eyeball centers lie in a straight line, the eyeball centers can be observed as the position of the iris-center. Using data from these observations enables us to easily obtain the relations between the eyeball centers and facial features. Experimental results show that the gaze estimation accuracy of the proposed method is $4^{\circ}$ horizontally and $7^{\circ}$ vertically.
\end{abstract}

キーワード : 視線推定, 視線インタフェース, 虹彩, 眼球

\section{1. ま え がき}

視線情報には, コンピュータインタフェースとしての利 用やユーザの意図検出など，多くの忘用が考えられるため， これまでにさまざまな視線推定手法が提案されている.

視線推定手法としては, 近赤外の点光源 (LED) により 目を照明し, 角膜で反射された光源像 (プルキニエ像) と瞳 孔の位置から視線方向を推定する睲孔角膜反射法が一般的 であった ${ }^{1 / 2)}$ 。これらの手法では, 推定䛊差が 1 度程度と 比較的高精度な結果が得られる. 一方で, 赤外光源によっ て目領域を照明する必要があるため, 視線の検出可能範囲 がカメラ (赤外照明)の近傍に限られるといった問題や, プ ルキニエ像を検出するために目領域の高解像度画像を必要 とするという問題がある. また，力メラに加えて赤外照明 が必要なため, 装置構成が複雑になるという問題もある.

これに対し，ビデオカメラのみを用いて通常の画像から 視線を推定する手法が近年提案されている ${ }^{3) \sim 12)}$ 。これら の視線推定手法は, アピアランスベースとモデルベースの 大きく 2 種類に分けることができる.

アピアランスベースの手法は, 目周辺の画像を入力とし, ニューラルネットワークや最近傍探索といったパターン認

2007 年 5 月 2 日受付, 2007 年 7 月 20 日再受付, 2007 年 8 月 22 日採録 †ATR 知能ロボティクス研究所

（テ 619-0288「けいはんな学研都市」光台 2-2-2, TEL 0774-95-1405)

$\dagger$ ATR Intelligent Robotics \& Communication Laboratories

(2-2-2, Hikaridai, Keihanna Science City, Kyoto 619-0288, Japan)

$1750(70)$
識手法を利用することで, 視線方向を推定することを目指 した手法である ${ }^{3) 5)}$ ，これらの手法では，ユーザの違いや 頭部の姿勢変化, 目領域の切り出し誤差などによって視線 推定結果が大きく影響を受けるという問題があり, 視線推 定に大量の学習データを必要とするという問題もある.

モデルベースの手法は, 3 次元の眼球モデルを用いて視 線方向を推定するもので, さらに二つに分類することがで きる. 一つは, "one-circle (two-circle)"アルゴリズムであ り，観測された虹彩領域に対し，楕円を当てはめ，その楕 円パラメータから視線方向を推定するものである ${ }^{6) 7)}$.これ らの棈円当てはめを利用した手法では, 虹彩の形状から直 接視線方向を検出できるため, 事前のキャリブレーション が必要ないという利点がある. しかし，正確に楕円を当て はめるためには高解像度の目領域画像が必要である, ユー ザがカメラに近い方向を見ている場合には, 虹彩がほぼ円 として観測されるため楕円当てはめ精度が低下し, 視線推 定精度が低下する，といった問題がある.

もう一つのモデルベースの手法は, 眼球中心と虾彩中心 を結ぶ 3 次元べクトルとして視線方向を推定するものであ る ${ }^{8) ~ 12)}$. 眼球中心位置や眼球半径といったパラメータは, 画像から直接観測することはできないため，顔に貼付した 人為的なマーカや目・鼻・ 口などの自然特徴などの顔面上 の特徵点と眼球中心との相対関係をあらかじめモデル化し ておくことで, 顔特徴点を追跡することにより間接的に眼 球中心を推定し，視線方向を推定しており，3〜 5 度程度の 
推定精度が得られている.

Matsumoto $~^{8)}$ や Pogalin ${ }^{11)}$ はあらかじめ顔特徵点 (目頭・目尻) と眼球中心の関係を求めておき, ステレオカ メラにより顔特徴を追跡することで, 視線方向を推定する 手法を提案している. しかし, これらの手法ではステレオ カメラを用いており, 事前にカメラ間のキャリブレーショ ンが必要なためカメラの観測範囲の変更が容易ではないと いう問題がある.

Ishikawa らは, 8),11) と同様に目頭・目尻と眼球中心の 関係を利用し, Active Appearance Model(AAM)により 顔特徴を追跡することで, 単眼による視線推定手法を提案 している ${ }^{10)}$. しかし, 眼球中心の推定に, 頭部姿勢・視線 方向が既知の複数枚の画像列を必要とするため, キャリブ レーションにかかる手間が大きいという問題がある.

これに対し, 我々は顔に装着した四つの参照点を利用し た視線推定手法を提案した ${ }^{12)}$. 四つの参照点は原理的には 同一平面上でなければ位置的な制限はなく, 四つの参照点 から眼球中心を推定し, 眼球中心と虹彩中心を結ぶ 3 次元 ベクトルとして視線方向を推定する. この手法では, ユー ザがカメラを注視したときにはカメラと虹彩中心, 眼球中 心が一直線上に並ぶという性質を利用し, 眼球中心の投影 位置を虹彩中心として観測することにより, ユーザがカメ ラを注視しながら頭部姿勢を任意に変化させるだけで, 眼 球中心を推定することが可能となっている.

本論文では，手法 12) を搪張し，マーカを顔に装着する 代わりに顔の特徴点を追跡することにより, 視線方向を推 定する手法を提案する.

次章では, 提案手法における視線推定の原理と提案手法 の処理の流れについて簡単に述べる. 3 章では提案する視 線推定手法について説明し，4章で実画像を用いた実験に より提案手法の有効性を示す. 5 章で本論文をまとめる.

\section{2. 提案手法の概要}

\section{1 視線推定の原理}

提案手法では, 視線方向は眼球中心と虹彩中心を結ぶ 3 次元ベクトルとして検出できるとする (図 1). 画像上の 眼球中心位置を $\boldsymbol{x}_{c}=\left[x_{c}, y_{c}\right]$, 虹彩中心位置を $\boldsymbol{x}_{\text {iris }}=$ $\left[x_{i r i s}, y_{i r i s}\right]$, 画像上での眼球投影半径を $r$ とする. 視線方 向 (カメラ光軸とのなす角) のカメラ座標系 $x$ 軸方向成分 $\alpha_{i}$ と $y$ 軸方向成分 $\beta_{i}$ は次式で求められる.

$$
\begin{aligned}
& \alpha_{i}=\sin ^{-1}\left(\frac{x_{i r i s}^{(i)}-x_{c}^{(i)}}{r^{(i)}}\right), \\
& \beta_{i}=\sin ^{-1}\left(\frac{y_{\text {iris }}^{(i)}-y_{c}^{(i)}}{r^{(i)}}\right) .
\end{aligned}
$$

一方で, 眼球半径は解剖学的なパラメータより推定可能で あり, 虹彩中心は画像から観測可能であるが, 眼球中心位 置は，画像から直接求めることはできない.

ここで, ユーザがカメラを注視した場合について考える

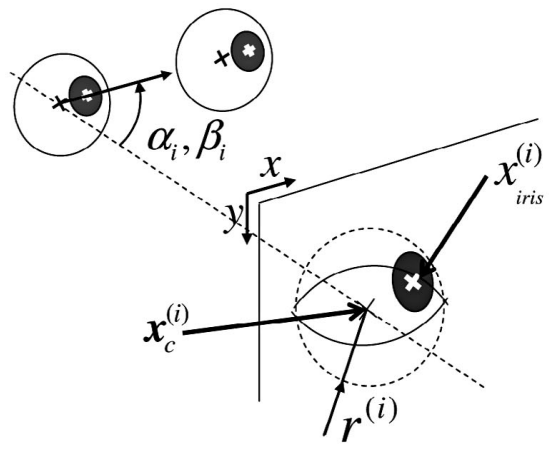

図 1 視線推定の原理 Gaze estimation model.

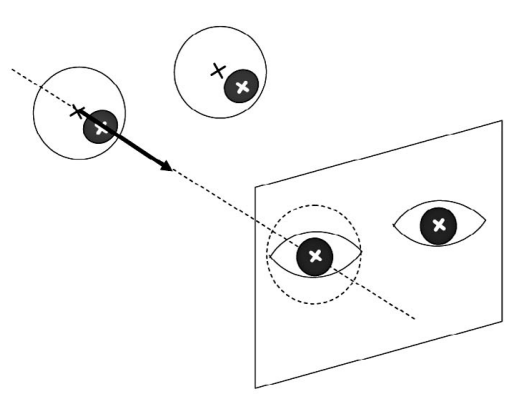

図 2 視線推定の原理 (キャリブレーション時) Gaze estimation model (calibration process).

と, 図 2 に示すとおり, カメラ, 虹彩中心, 眼球中心の 3 点が 1 直線上に並ぶため, 画像上では虾彩中心と眼球中心 は同一点に投影されることがわかる.

そこで提案手法では，ユーザがカメラを注視しながら顔 の姿勢を変化させている画像列を撮影し，これらの画像列 から顔特徴点を抽出・追跡するとともに, 眼球中心位置と して虹彩中心を抽出することで, 眼球中心と顔特徵点間の 相対幾何関係を推定することを考える.

\section{2 提案手法の処理の流れ}

図 3 に提案手法による処理の流れを示す. 本システムの 処理は単眼カメラをべースとして抢り, 顔位置の検出が可 能で光学的に充分なズーム比が得られれば観測距離の制約 を受けない. 図 3 に提案手法の処理の流れを示す. 提案手 法は顔検出・顔特徴追跡処理, 顔モデル推定処理 (キャリブ レーション), 視線推定処理の三つの処理からなる.

顔検出・顔特徴追跡処理では, 3 次元モデル生成や視線 推定で用いる顔特徵の抽出・追跡を行う.まず 6 分割矩形 フィルタ (Six-Segmented Rectangular(SSR) Filter) を用 いた顔検出処理 ${ }^{13)}$ により, 画像上の顔位置を決定する. 次 に日・鼻・口などの位置関係を用いて顔特徴点を抽出・追 跡する. 特徴点の抽出・追跡には, Lucas-Kanade の特徵 点を用いた ${ }^{14)}$.

顔モデル推定処理では, 顔特徴点と眼球中心の相対幾何 関係を求めるため, ユーザがカメラを注視しながら頭部姿 勢を任意に変化させた画像列を撮影し, 顔特徵の抽出・追跡 を行うとともに，両目の虹彩中心を抽出する. 得られた顔 特徵点列と虹彩中心位置をもとに因子分解法 ${ }^{15)}$ を用いて, 顔特徵点と眼球中心の 3 次元位置 (顔モデル) を算出する. 


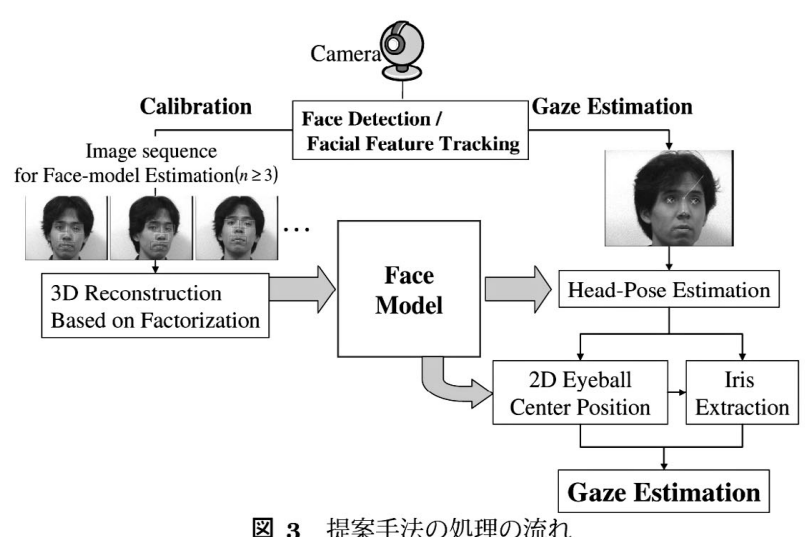

Process flow of the proposed method.

視線推定処理では，まず新規の入力画像列に対して顔特 徵および虹彩中心位置の追跡・検出を行う．次に顔特徴点 の観測位置をもとに顔の 3 次元モデルを用いて眼球中心の 投影位置を推定する. 虹彩中心位置および眼球中心投影位 置から (1) 式により視線方向を決定する.

\section{3. 顔特徵の追跡による視線推定}

\section{1 顔特徵点の抽出・追跡}

本節では, 目, 鼻などの顔特徴点を抽出し, 追跡する手 法について述べる.

まず 6 分割矩形 (SSR) フィルタとサポートベクタマシン (SVM) による顔検出手法 ${ }^{13)}$ を用いて, 画像中の顔位置を 検出する.SSR フィルタ (図 4)では, 目扔よび目周辺領域 は顔の他領域に比べて輝度值が低いことを利用し, 次式を 満たす点を顔候補として抽出する.

$$
\begin{array}{lll}
\bar{S}_{1}<\bar{S}_{2} & \text { and } & \bar{S}_{1}<\bar{S}_{4}, \\
\bar{S}_{3}<\bar{S}_{2} & \text { and } & \bar{S}_{3}<\bar{S}_{6} .
\end{array}
$$

ここで $\bar{S}_{i}$ は領域 $S_{i}$ 内の平均輝度值.

次に得られた顔候補に対して, サポートベクタマシン (SVM) による顔モデルによる検証処理を適用し顔領域を決 定する. 髪型の違いや䯺の有無, 表情変化による認識率の 低下を避けるため, 手法 13) では眉間を中心とした画像領 域を利用して SVM によるモデル化を行っている.

次に, 目・鼻・口など顔特徴の位置関係を考慮しながら, 顔検出結果をもとに各顔特徵のおおまかな位置を決定する. さらにそれらの位置の周辺領域に対して, Lucas-Kanade の特徴点 ${ }^{14)}$ を検出し, 顔特徴点を抽出する (図 5). ここで, $M$ 点の顔特徴点 $p_{j}(j=1, \ldots, M)$ を抽出することとし, 画

\begin{tabular}{|c|c|c|c|}
\hline$i_{1}$ & $S_{1}$ & $S_{2}$ & $S_{3}$ \\
\hline$h_{2}$ & $S_{4}$ & $S_{5}$ & $S_{6}$ \\
\hline
\end{tabular}
像 $I_{i}$ 上での各顔特徵点列 $p_{j}$ の 2 次元位置を $\boldsymbol{x}_{j}^{(i)}$, 重心を

図 46 分割矩形 (SSR) フィルタ Six-segmented rectangular(SSR) filter.
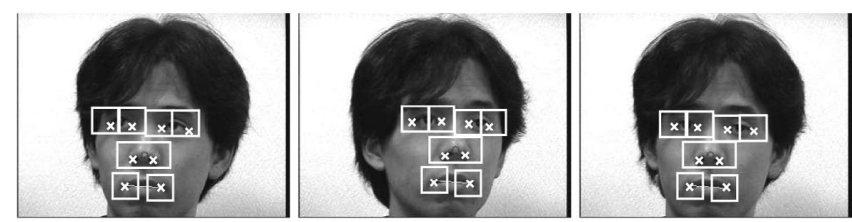

図 5 顔特徴点抽出の例

(白枠は顔特徴の探索範囲, $\times$ 印が抽出された顔特徵点)

Example of face detection.

(Box: searching area of facial features, $x$ : detected facial features.)

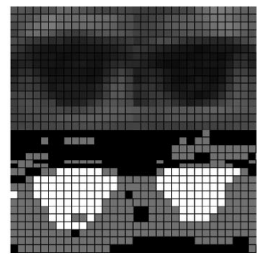

図 6

6 目周辺領域のラベリング例 (向: 虹彩, 灰: 白目, 黒: 肌)

Eye-region segmentation.

(white: iris, gray: sclera, black: skin)

$\overline{\boldsymbol{x}}^{(i)}=\frac{1}{M} \sum_{j=1}^{M} \boldsymbol{x}_{j}^{(i)}$ で表す.

\section{2 虹彩中心の推定}

ここでは, 虹彩中心位置を推定する手法について説明す る. ここで述べる処理は, キャリブレーション時・視線推 定時の両方で利用する.

まず前節の処理で得られた目周辺領域に対して, 輝度・ 色情報をもとに虹彩, 白目, 肌領域の 3 領域にラベリング を行う. 図 6 にラベリング結果の例を示す．次に，得られ た各領域のうち, 虹彩と白目の境界部分に着目し，八フ変 換により円を当てはめ, 得られた円の中心を虹彩中心位置 として決定する. 図 7 に虹彩中心推定の例を示す.

\section{3 顔モデル・眼球半径の推定}

次に, 視線推定の前処理である顔モデルと眼球半径の推 定処理について述べる.ここで述べる処理は，キャリブレー ション時に一度だけ実行される。

まず，キャリブレーション用の画像列として，前述のと おりユーザがカメラを注視しながら，顔の姿勢を変化させ ている画像列を撮影する. ここで, $N(N \geqq 3)$ 枚の画像列 $I_{i}$ が得られたとする $(i=1, \ldots, N)$.

次に, この画像から $M$ 点の顔特徴点 $p_{j}$ を抽出・追跡す る. 同時に, 左右両目の虹彩中心位置を抽出し, それぞれ $\boldsymbol{x}_{\text {irisL }}^{(i)}, \boldsymbol{x}_{\text {irisR }}^{(i)}$ とすると,

$$
\begin{gathered}
\boldsymbol{W}=\left[\begin{array}{ccc}
\boldsymbol{x}_{1}^{(1)}-\overline{\boldsymbol{x}}^{(1)} & \cdots & \boldsymbol{x}_{M}^{(1)}-\overline{\boldsymbol{x}}^{(1)} \\
\vdots & & \vdots \\
\boldsymbol{x}_{1}^{(N)}-\overline{\boldsymbol{x}}^{(N)} & \cdots & \boldsymbol{x}_{M}^{(N)}-\overline{\boldsymbol{x}}^{(N)} \\
\boldsymbol{x}_{\text {irisL }}^{(1)}-\overline{\boldsymbol{x}}^{(1)} & \boldsymbol{x}_{\text {irisR }}^{(1)}-\overline{\boldsymbol{x}}^{(1)} \\
\vdots & \vdots \\
& \boldsymbol{x}_{\text {irisL }}^{(N)}-\overline{\boldsymbol{x}}^{(N)} & \boldsymbol{x}_{\text {irisR }}^{(N)}-\overline{\boldsymbol{x}}^{(N)}
\end{array}\right],
\end{gathered}
$$

で表される行列 $\boldsymbol{W}$ は，因子分解法により 次式のとおり分 解できる ${ }^{15)}$. 


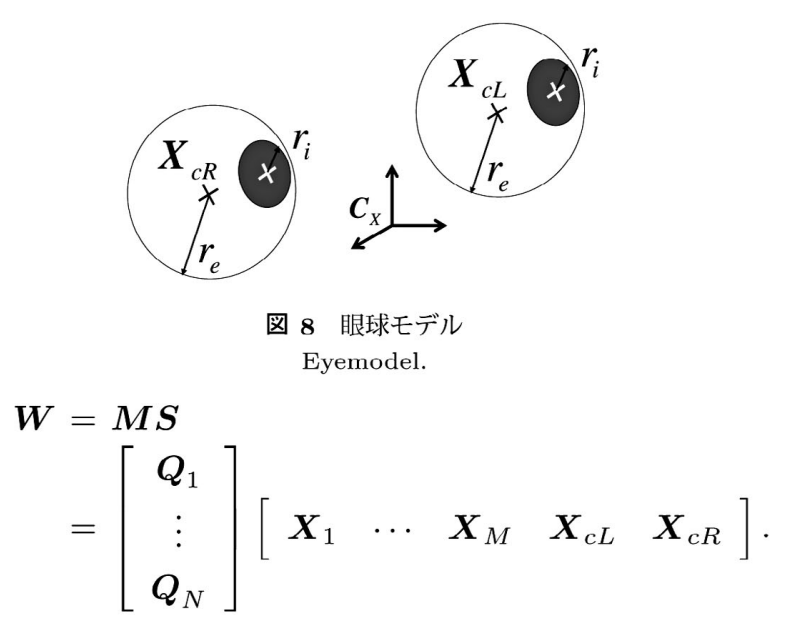

ここで, $\boldsymbol{M}$ は姿勢変化に関する行列, $\boldsymbol{Q}_{i}$ は $2 \times 3$ の行列. $\boldsymbol{S}$ は顔モデル (顔特徴点・眼球中心の 3 次元位置) であり, $\boldsymbol{X}_{j}$ は顔モデル座標系 $\boldsymbol{C}_{X}$ における各顔特徴点の 3 次元位 置, $\boldsymbol{X}_{c L}, \boldsymbol{X}_{c R}$ は眼球中心の 3 次元位置である (図 8).

以上で求められた顔モデル $\boldsymbol{S}$ (顔特徴点の 3 次元位置 $\boldsymbol{X}_{j}$ と眼球中心位置 $\left.\boldsymbol{X}_{c L}, \boldsymbol{X}_{c R}\right)$ を用いることで, 新規に得ら れた画像 $I_{t} に$ にいて眼球中心位置は以下のように計算で きる.

$I_{t}$ における顔特徴点が $\boldsymbol{x}_{1}^{(t)}, \ldots, \boldsymbol{x}_{M}^{(t)}$ の位置にそれぞれ観 測されたとする. (4),(5) 式より, 顔特徵点の観測位置 $\boldsymbol{x}_{j}^{(t)}$ と 3 次元位置 $\boldsymbol{X}_{j}$ の関係は次式で表される.

$$
\begin{aligned}
\boldsymbol{x}_{j}^{(t)} & =\boldsymbol{Q}_{t} \boldsymbol{X}_{j}+\overline{\boldsymbol{x}}^{(t)} \\
& =\boldsymbol{P}_{t}\left[\begin{array}{c}
\boldsymbol{X}_{j} \\
1
\end{array}\right]
\end{aligned}
$$

ただし $\boldsymbol{P}_{t}=\left[\begin{array}{ll}\boldsymbol{Q}_{t} & \overline{\boldsymbol{x}}_{t}\end{array}\right]$. ここで, 行列 $\boldsymbol{Q}_{i}$ は弱透視変換 における投影行列とみなせるため, $\mathrm{QR}$ 分解により以下の ように計算できる ${ }^{16)}$.

$$
\boldsymbol{Q}_{t}=\boldsymbol{A}_{t} \cdot \boldsymbol{R}_{t}^{(2 \times 3)}
$$

ただし $\boldsymbol{R}_{t}^{(2 \times 3)}$ は姿勢情報を含む $2 \times 3$ の行列. $\boldsymbol{A}_{t}$ はカメ ラの内部パラメータであり,

$$
\boldsymbol{A}_{t}=k_{t}\left[\begin{array}{cc}
\xi & 0 \\
s & 1
\end{array}\right]
$$

$k_{t}$ はスケールファクタ. 理想的には $\xi=1, s=0$. ここで, 行列 $\boldsymbol{P}_{t}$ は 4 点以上の顔特徴点 $\boldsymbol{x}_{i_{1}}^{(t)}, \ldots, \boldsymbol{x}_{i_{S}}^{(t)}(s \leqq 4)$ が観 測されれば，以下のとおり計算できる.

$$
\begin{aligned}
& \boldsymbol{B =} \\
& {\left[\begin{array}{cccccccc}
X_{i_{1}}^{(t)} & Y_{i_{1}}^{(t)} & Z_{i_{1}}^{(t)} & 1 & 0 & 0 & 0 & 0 \\
0 & 0 & 0 & 0 & X_{i_{1}}^{(t)} & Y_{i_{1}}^{(t)} & Z_{i_{1}}^{(t)} & 1 \\
\vdots & & & & & & & \vdots \\
X_{i_{s}}^{(t)} & Y_{i_{s}}^{(t)} & Z_{i_{s}}^{(t)} & 1 & 0 & 0 & 0 & 0 \\
0 & 0 & 0 & 0 & X_{i_{s}}^{(t)} & Y_{i_{s}}^{(t)} & Z_{i_{s}}^{(t)} & 1
\end{array}\right]}
\end{aligned}
$$

論 文口顔特徴点追跡による単眼視線推定

$$
\begin{aligned}
& \boldsymbol{C}=\left[\begin{array}{lllll}
x_{i_{1}}^{(t)} & y_{i_{1}}^{(t)} & \cdots & x_{i_{s}}^{(t)} & y_{i_{s}}^{(t)}
\end{array}\right]^{\prime} . \\
& \boldsymbol{p}=\left(\boldsymbol{B}^{\prime} \boldsymbol{B}\right)^{-1} \boldsymbol{C}, \\
& \boldsymbol{P}_{t}=\left[\begin{array}{llll}
p_{1} & p_{2} & p_{3} & p_{4} \\
p_{5} & p_{6} & p_{7} & p_{8}
\end{array}\right] .
\end{aligned}
$$

ただし, $\boldsymbol{p}=\left[\begin{array}{llllllll}p_{1} & p_{2} & p_{3} & p_{4} & p_{5} & p_{6} & p_{7} & p_{8}\end{array}\right]^{\prime}$, $\boldsymbol{X}_{i}=\left[\begin{array}{ccc}X_{i} & Y_{i} & Z_{i}\end{array}\right]^{\prime}, \boldsymbol{x}_{i}=\left[\begin{array}{ll}x_{i} & y_{i}\end{array}\right]^{\prime}$. ここで'は行 列の転置を表す.

よって, 画像 $I_{t}$ における両目の眼球中心位置 $\boldsymbol{x}_{c L}^{(t)}, \boldsymbol{x}_{c R}^{(t)}$ は (6) 式より以下のとおり計算できる.

$$
\begin{aligned}
& \boldsymbol{x}_{c L}^{(t)}=\boldsymbol{P}_{t}\left[\begin{array}{c}
\boldsymbol{X}_{c L} \\
1
\end{array}\right], \\
& \boldsymbol{x}_{c R}^{(t)}=\boldsymbol{P}_{t}\left[\begin{array}{c}
\boldsymbol{X}_{c R} \\
1
\end{array}\right] .
\end{aligned}
$$

\section{4 視線推定}

新たに観測される入力画像について，前節までで得られ た顔モデルと眼球半径を利用して, 視線方向を推定する.

時刻 $t$ における画像 $I_{t}$ に対し, まず顔特徴点の追跡と虹 彩中心位置の抽出を行い, 顔特徴点が $\boldsymbol{x}_{1}^{(t)}, \ldots, \boldsymbol{x}_{M}^{(t)}$, 虹彩 中心が $\boldsymbol{x}_{\text {irisL }}^{(t)}, \boldsymbol{x}_{\text {irisR }}^{(t)}$ の位置にそれぞれ観測されたとする.

4 点以上の顔特徴点が観測されると，(12) 式により眼球 中心の投影位置 $\boldsymbol{x}_{c L}^{(t)}, \boldsymbol{x}_{c R}^{(t)}$ を計算できるので, 視線方向の カメラ座標系 $x$ 軸方向成分 $\alpha_{t}, y$ 軸方向成分 $\beta_{t}$ は次式に より計算できる.

$$
\begin{aligned}
& \alpha_{t}=\sin ^{-1}\left(\frac{x_{\text {iris }}^{(t)}-x_{c}^{(t)}}{r^{(t)}}\right) \\
& \beta_{t}=\sin ^{-1}\left(\frac{y_{\text {iris }}^{(t)}-y_{c}^{(t)}}{r^{(t)}}\right) .
\end{aligned}
$$

ここで, 現在の実装では眼球半径 $r^{(i)}$ については, 眼球半 径と眼間距離の解剖学的なモデルをもとに求めたパラメー タを用いた．ただし，各ユーザにあわせた眼球半径を推定 する場合には，方向既知の参照点を注視させた各ユーザの 画像列を撮影し，これら画像列を用いてキャリブレーショ ンを行う必要がある.

\section{4. 実 験}

提案手法の有効性を確認するため, 以トの実験を行った. 実験環境の様子を図 9 に示す. Panasonic 社製 DV カメ ラ NV-GS200K を被験者の正面 $220[\mathrm{~cm}]$ の位置に設置し, $320 \times 240$ の解像度で被験者の顔画像を撮影した．撮影画 像上の目領域の大きさは約 $30 \times 15$ [pixel], 虹彩半径は約 6[pixel] である. 視線推定の精度を評価するために, 被験 者正面の距離 $240[\mathrm{~cm}]$ の壁面上に 28 個のマーカを図 10 に 示すように設置した.

5 名の被験者 (眼鏡なしの男性 3 名 (被験者 1-3), 女性 1 
名 (被験者 4), 眼鏡ありの男性 1 名 (被験者 5)) について, 提案手法により視線を推定し，その精度を評価した. 実験 では, まず 50 枚の画像列を撮影し, 各被験者の顔モデルを 推定した. 推定に要した時間は約 3 秒である. 図 11 に顔 モデル推定に用いた画像列の例を示す.

顔モデル推定後, 各被験者にはマーカをそれぞれ 5 秒ず つ順に注視するように指示し，視線推定処理を行つた．視 線推定時の処理速度は, 約 10 フレーム/秒である. 図 12 斜線領域に示すように, 各マーカごとのデータの中央部分 30 フレーム分の推定值を利用し, 各方向に対する視線推定 誤差を測定した. 表 1 に各被験者における視線推定䛊差を 示す. 結果より, 水平方向は約 4 度, 垂直方向は約 7 度の 推定精度が得られていることわかる (実駼環境のマーカ平 面において， 5 度は約 $20 \mathrm{~cm}$ に相当). 眼鏡をかけている被 験者 5 についても, 他の被験者と同様の推定精度が得られ ており，眼鏡の枠などにより虹彩が隠蔽されなければ，提 案手法による視線推定が可能であることがわかる.

次に, 注視方向による視線推定精度の変化を確認するた

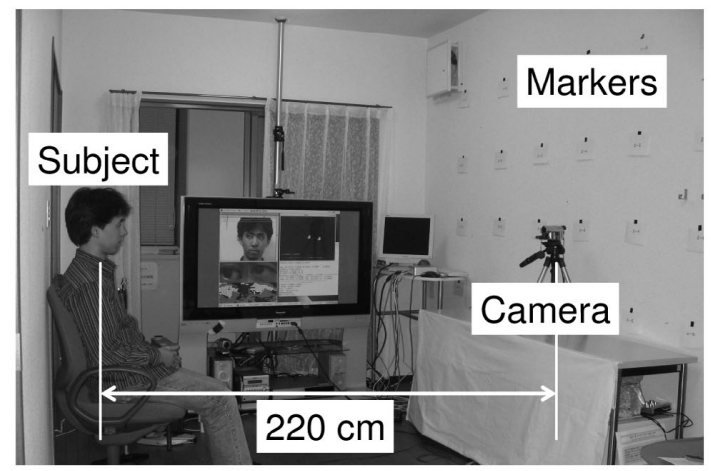

図 9 実験環境

Experimental environment.

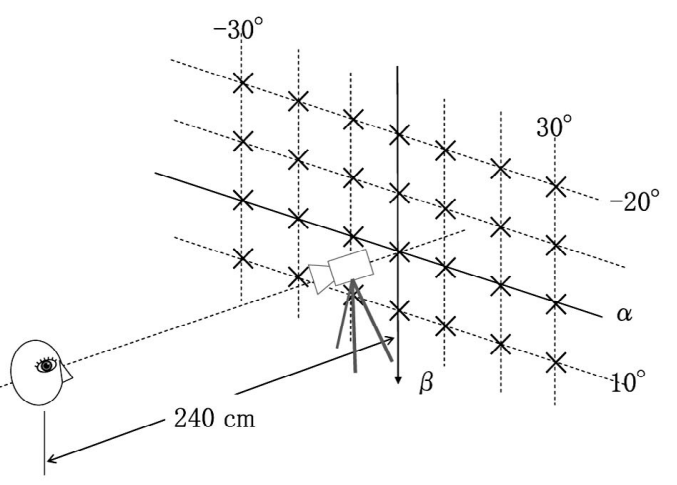

図 10 マーカ配置

Marker arrangement.

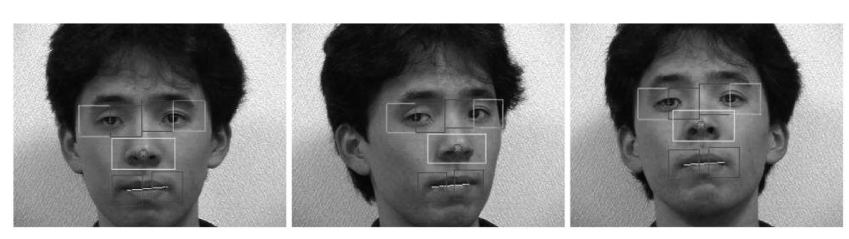

図 11 キャリブレーション画像列の例

Examples of calibration image sequences.

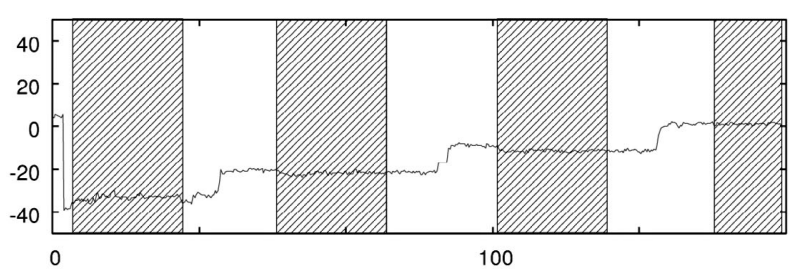

図 12 視線推定結果と誤差評価データ Gaze estimation results and error evaluation.

表 1 視線推定誤差 (平均)

Average of the estimation errors

\begin{tabular}{l|r|r}
\hline \hline & Horizontal[deg] & Vertical [deg] \\
\hline Subject 1 & 5.59 & 8.68 \\
Subject 2 & 2.26 & 7.31 \\
Subject 3 & 4.78 & 9.73 \\
Subject 4 & 5.50 & 6.49 \\
Subject 5 & 3.65 & 5.55 \\
\hline Average & 4.36 & 7.55 \\
\hline
\end{tabular}

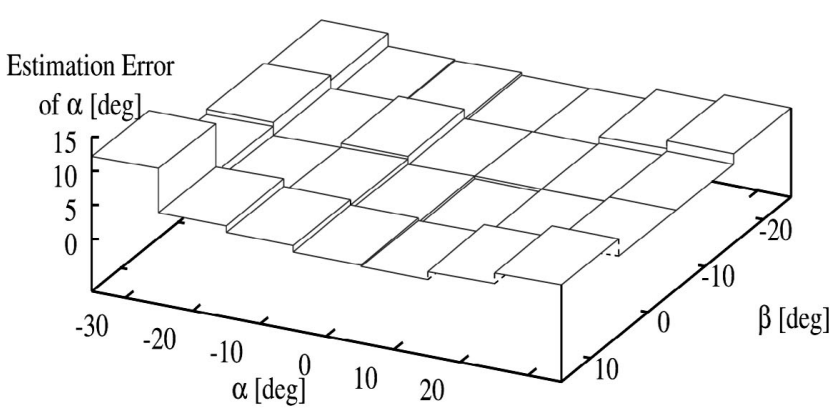

図 13 各マーカ $(\alpha, \beta)$ に関する視線推定䛊差 (水平方向) Estimation Error at each marker (horizontal errors).

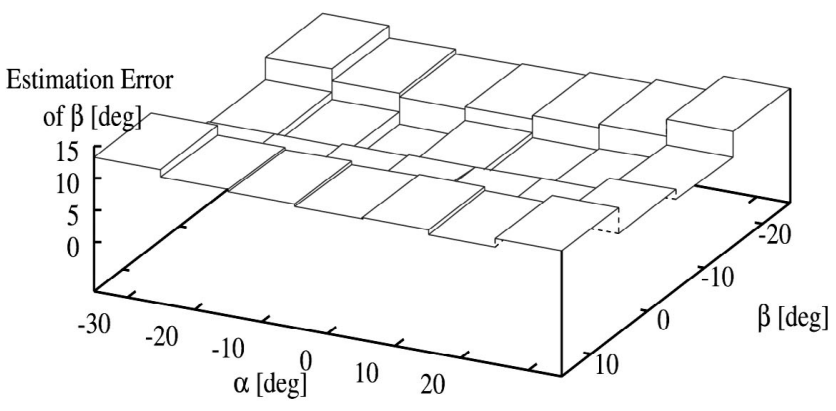

図 14 各マーカ $(\alpha, \beta)$ に関する視線推定䛊差 (垂直方向) Estimation Error at each marker (vertical errors).

め, 各マーカ $(\alpha, \beta)$ に関する視線推定䛊差 (水平・垂直方 向)の全被験者の平均を図 13,14 に示す. 図 13 より, 注 視方向の違いによって水平方向の視線推定精度には, 特に 変化がないことがわかる，一方で図 14 より，垂自方向に関 しては, 注視方向の角度 ( $\beta$ の絶対值) が大きくなるに伴い, 推定䛊差が大きくなっていることがわかる.これは， $\beta$ 方 向に視線を変化させた場合には，まぶたによって隠蔽され る虹彩領域が広くなり, 虹彩中心の推定精度が悪化したた めと考えられる.

最後に, 図 15 にすべての被験者の視線推定結果画像の 例を示す. 以上の結果より, 提案于法を用いることで, さ まざまなユーザについて頭部姿勢の変化する場合でも視線 推定が可能であることが示された. 

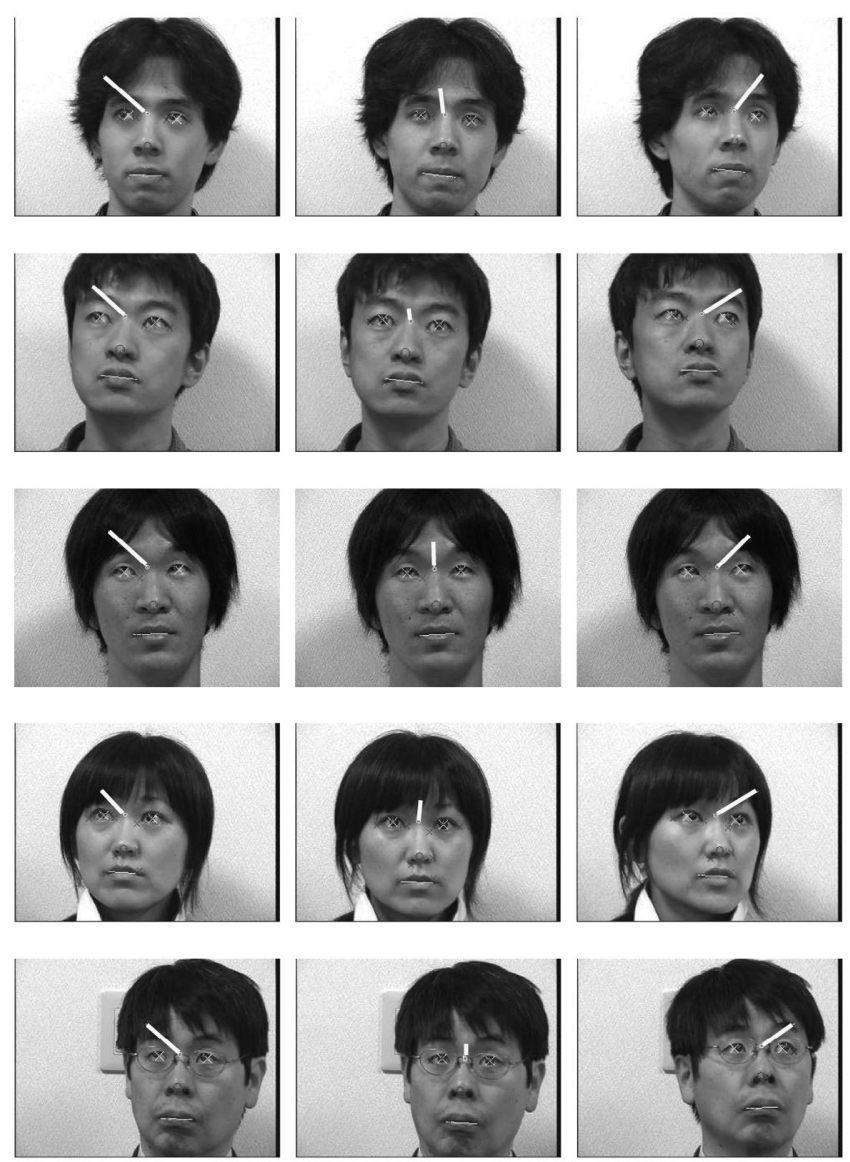

図 15 視線推定結果

$\left(\right.$ 左から $(\alpha, \beta)=\left(-20^{\circ},-20^{\circ}\right),\left(0^{\circ},-10^{\circ}\right),\left(20^{\circ},-20^{\circ}\right)$ Experimental results.

(from left, $(\alpha, \beta)=\left(-20^{\circ},-20^{\circ}\right),\left(0^{\circ},-10^{\circ}\right),\left(20^{\circ},-20^{\circ}\right)$.

\section{5. むすび}

本論文では, 単眼カメラの観測に基づいて顔特徵点を検 出・追跡することにより視線方向を推定する于法を提案し た. 提案手法では, まずキャリブレーションとして視線が

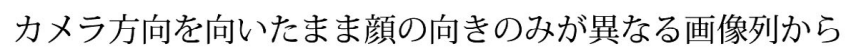
得られる虹彩位置と顔特徴点を利用することで, 眼球中心 と顔特徴点の関係をモデル化し, その後, その関係に基づ いて推定された入力画像中の眼球中心位置と虹彩位置の関 係から視線方向を決定している. 提案手法は単眼カメラに よる観測画像から視線方向を推定し, 赤外照明を必要とし ないため, 光学的に充分なズーム比を得ることができれば, 観測距離の制約を受けずに視線推定が可能である.これに より従来の視線推定装置では実現が難しかった遠方・広範 囲における視線推定が可能になる.

今後は, 顔特徴追跡処理や虹彩抽出処理の高精度化によ り視線推定の精度向上を図るとともに, 複数のカメラやパ ンチルトカメラを利用した広範囲における視線推定につい ても検討を進める予定である.

本研究は, 情報通信研究機構 (NICT) の研究委託により 実施したものである.
〔文

\section{献了}

1) T. Ohno, N. Mukawa, and S. Kawato. Just blink your eyes: A head-free gaze tracking system. In Proc. CHI2003, pp. 950-951 (2003)

2) C. H. Morimoto and M. R. M. Minica. Eye gaze tracking techniques for interactive applications. Computer Vision and Image Understanding, 98, 1, pp. 4-24 (2005)

3) B. Shiele and A. Waibel. Gaze tracking based on facecolor. In Proc. Int'l Workshop on Automatic Face and Gesture Recognition, pp. 344-349, (1995)

4）小野泰弘, 岡部孝弘, 佐藤洋一. 目領域の切り出しの不定性を考慮した低 解像度画像からの視線方向推定. 情処論, 47, SIG 10(CVIM 15), pp. 173-184 (2006)

5) L. P. Morency, C.M. Chrristoudias, and T. Darrell. Recognizing gaze aversion gestures in embodied conversational discourse. In Proc. ICMI'06, pp. 287-294 (2006)

6) J.G. Wang, E. Sung, and R. Venkateswarlu. Estimating the eye gaze from one eye. Computer Vision and Image Understanding, 98, 1, pp. 83-103 (2004)

7）北川洋介, 加藤义和, 呉海元, 和田俊和. アイモデルを用いた視線推定 のための黒目追跡. 画像の認識・理解シンポジウム (MIRU2005), pp. 1343-1350 (2005)

8) Y. Matsumoto and A. Zelinsky. An algorithm for real-time stereoo vision implementation of head pose and gaze direction measurement. In Proc. Int. Conf. Automatic Face and Gesture Recognition, pp. 499-504 (2000)

9) T. Miyake, S. Haruta, and S. Horihata. Image based eye-gaze estimation irrespective of head direction. In Proc. IEEE Int. Symp. Industrial Electronics, 1, pp. 332-336 (2002)

10) T. Ishikawa, S. Baker, I. Matthews, and T. Kanade. Passive driver gaze tracking with active appearance models. In Proc. 11th World Congress on Intelligent Transportation Systems (2004)

11) E. Pogalin, A. Redert, I. Patras, and E.A. Hendriks. Gaze tracking by using factorized likelihooods particle filtering and stereo vision. In Proc.3DPVT'06, pp. 57-64 (2006)

12) S. Kawato, A. Utsumi, and S. Abe. Gaze direction estimation with a single camera based on four reference points and three calibration images. In Proc. ACCV2006 (I), pp. 419-428 (2005)

13) S. Kawato, N. Tetsutani, and K. Hosaka. Scale-adaptive face detection and tracking in real time with ssr filters and support vector machine. IEICE Trans. on Info. and Sys., E88-D, 12, pp. 2857-2863 (2005)

14) B.D. Lucas and T. Kanade. An iterative image registration technique with an application to stereo vision. In Proc.Int'l Joint Conf. Aretificial Intelligence, pp. 674-679 (1981)

15) C. Poelman and T. Kanade. A paraperspective factorization method for shape and motion recovery. Technical Report 92-208, CMU-CS (1992)

16) Long Quan. Self-calibration of an affine camera from multiple views. Int'l Journal of Computer Vision, 19, pp. 93-105 (1996)

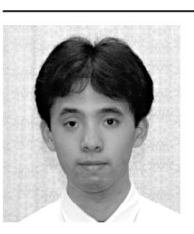

岀箔哭笑

山 2000 年, 大阪大学基礎工学部シス テム工学科卒業. 2002 年, 大阪大学基礎工学研究科修士 課程修了. 2005 年, 大阪大学大学院基礎工学研究科博士 課程修了. 2005 年 4 月, ATR メディア情報科学研究所 専任研究員. 2006 年 4 月より, ATR 知能ロボティクス 研究所専任研究員. 博士 (工学). 正会員.

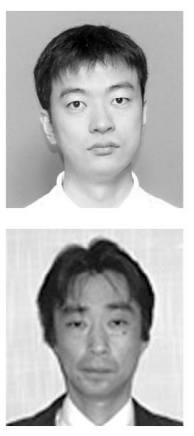

內つ海敏章 1991 年, 大阪府立大学工学部金属 工学科卒業. 1993 年, 人阪人学基礎工学研究科情報工学 修士課程修了. 同年, ATR 通信システム研究所に入社. 画像処理, ヒューマンインタフェースの研究に従事. 現 在, ATR 知能ロボティクス研究所ならびに ATR メディ ア情報科学研究所主任研究員. 博士 (工学).

安部 伸 治 1984 年 北海道大学工学部原子工学 科卒業. 1986 年 同大学院工学研究科修士課程修了. 同 年日本電信電話 (株) 入社. ヒューマンインタフェース研 究所・サイバーソリューション研究所にて, 画像・映像 ハンドリングなどに関する研究に従事. 現在 ATR 知能 ロボティクス研究所にて認知症介護支援システムに関す る研究に従事. 